UDC 336.14

DOI: $10.17223 / 19988648 / 52 / 17$

\title{
Han-Sol Lee
}

\section{THE SUB-NATIONAL DISTRIBUTION OF SOUTH KOREAN FOREIGN DIRECT INVESTMENT IN RUSSIA: A FOCUS ON THE RUSSIAN FAR EAST}

\begin{abstract}
This paper investigates the Korean foreign direct investment (FDI) in the Russian Far East, a significant area to develop South Korea's new northern policy and Russia's pivot to the East policy. Unlike the insignificant influence of the Korean FDI on Russia's economy as a whole, South Korea is one of the key economic partners in the Russian Far East. For the period 2015-2019, South Korea is the 4th largest investor in the Russian Far East. In 2019, 69.7\% of the Korean investments in the Russian Far East concentrated on Primorsky Krai, which contradicts the general trend that the world investments in the Russian Far East are highly skewed in Sakhalin Oblast to participate in the gas and oil projects. The Korean FDI in the Russian Far East aims market seeking rather than resource seeking. Besides, due to the high entry barrier of "nine bridges", there are limited numbers of companies in nine bridges-industries.
\end{abstract}

Keywords: foreign direct investment, Russian Far East, South Korean economy, Russian economy, Eurasian economy.

In the middle of the global economic turbulences, South Korean economy achieved around 2 3\% annual growth rate for the period 2015-2019, and its per capita income exceeded $\$ 30,000$ in 2018 . However, economic growth based on skewed partnerships with only a few countries, for instance the USA and China, shapes South Korean economy highly vulnerable to economic crashes happening in those countries, and it significantly hinders the nation from building a strong and stable economy. Recently, the high dependency of Korean economy on China and the USA crept on to the main political agenda as the nation suffers series of losses amid the US-China trade war. It becomes certain that, for its further economic development, South Korea should not rely on the existing economic and political alliance but diversify economic and diplomatic relations to seize new growth opportunities and to become a leading country by own.

In this vein, in 2017, the Korean government introduced the two pillars of new foreign policies, namely, the new northern policy, and the new southern policy: the former is the policy to build partnerships with the Commonwealth of Independent States (CIS), Mongolia, and three northern provinces of China, while the latter is the policy to cooperate with Southeast Asian countries and India. Among the two diplomatic policies, the "new northern policy" is the agenda that this study should focus on in detail.

On the other hand, Russia planned the eastern policy for the development of regional economy, reduction of dependency on European economy, internationalization of the national economy, and engagement in multilateral 
security cooperation. In 2009, the federal government of Russia ordered the Strategy for the Socioeconomic Development of the Far East and the Baikal Region for the Period up to 2025 (N 2094-p). In 2012, the government officially addressed the new eastern policy in Measures to Implement the Russian Federation Foreign Policy, and, in 2013, the government adopted the state program Socioeconomic Development of the Russian Far East and the Baikal Region.

In this vein, to induce policy implications, this paper is dedicated to analyze the Korean foreign direct investment (FDI) in the Russian Far East, the key area where the new foreign policies of the two governments meet.

\section{The history of South Korea's northern policy}

The new northern policy is not a fresh idea, considering that South Korea has steadily promoted northern policies for more than three decades. South Korea's northern diplomacy began with the northern policy of Roh Tae-woo's regime in 1988, and after that it was succeeded to Kim Young-sam regime's globalization policy, Kim Dae-jung regime's sunshine policy, Lee Myung-bak regime's resource diplomacy, Park Geun-hye regime's Eurasian initiative, and Moon Jaein regime's new northern policy. Since 1988, South Korea has given up its hostile policies toward the communist nations, and begun to establish diplomatic relations with Eastern Europe, former Soviet Union, and China, to expand its political and economic horizons to the continent.

Table 1

The history of northern policy under each government regime in South Korea

\begin{tabular}{c|c|l}
\hline $\begin{array}{c}\text { President } \\
\text { (incumbency) }\end{array}$ & Policy name & \multicolumn{1}{c}{ Key features } \\
\hline $\begin{array}{c}\text { Roh Tae-woo } \\
(1988 \sim 1993)\end{array}$ & Northern policy & $\begin{array}{l}\text { Diplomatic establishment with the Soviet } \\
\text { Union and China. } \\
\text { South and North Korea's joining the UN }\end{array}$ \\
\hline $\begin{array}{c}\text { Kim Young-sam } \\
(1993 \sim 1998)\end{array}$ & $\begin{array}{l}\text { Globalization } \\
\text { policy }\end{array}$ & $\begin{array}{l}\text { South Korea's joining the OECD. } \\
\text { Containment policy toward North Korea and } \\
\text { worsening relations with Russia. } \\
\text { The rejection of South Korea's Three-Step } \\
\text { Unification Plan for the Construction of the } \\
\text { Korean Community from North Korea }\end{array}$ \\
\hline $\begin{array}{c}\text { Kim Dae-jung } \\
(1998 \sim 2003)\end{array}$ & Sunshine policy & $\begin{array}{l}\text { Economic support to North Korea (i.e. } \\
\text { permission of Mt. Geumgang tourism, } \\
\text { reunion of separated families, creation of } \\
\text { Gaesung Industrial Complex) and } \\
\text { strengthening relations with Russia } \\
\text { The 1st inter-Korean summit }\end{array}$ \\
\hline $\begin{array}{c}\text { Roh Moo-hyun } \\
\text { (2003 2008) }\end{array}$ & $\begin{array}{l}\text { Puccession and development of the sunshine } \\
\text { policy (i.e. operation of Gaesung Industrial } \\
\text { Complex, South-North Railway Connection) } \\
\text { The first overseas trip to Central Asia, } \\
\text { and Prosperity } \\
\text { namely Uzbekistan and Kazakhstan in 2004, } \\
\text { as South Korean president. } \\
\text { The 2 }{ }^{\text {nd }} \text { inter-Korean summit }\end{array}$ \\
\hline
\end{tabular}




\begin{tabular}{|c|c|c|}
\hline $\begin{array}{c}\text { President } \\
\text { (incumbency) }\end{array}$ & Policy name & Key features \\
\hline $\begin{array}{l}\text { Lee Myung-bak } \\
\text { (2008 2013) }\end{array}$ & $\begin{array}{l}\text { Resource } \\
\text { diplomacy }\end{array}$ & $\begin{array}{l}\text { Promotion of South Korea and Russia's silk } \\
\text { road cooperation in railway, gas (including } \\
\text { North Korea to build gas pipeline), and } \\
\text { agriculture, but absence of visible results. } \\
\text { Deterioration of inter-Korean relations due } \\
\text { to hard line policy }\end{array}$ \\
\hline $\begin{array}{c}\text { Park Geun-hye } \\
\text { (2013 2017) }\end{array}$ & Eurasia initiative & $\begin{array}{l}\text { A plan to make Eurasia one continent (to } \\
\text { build Eurasian transportation, energy, and } \\
\text { commerce networks), continent of creation } \\
\text { (to innovate economic structure and to create } \\
\text { new culture), and continent of peace (to } \\
\text { reduce security threat). } \\
\text { Eurasia Friendship Express from } \\
\text { Vladivostok to Berlin to commemorate the } \\
\text { 70th liberation day (one-time event). } \\
\text { Deterioration of inter-Korean relations due } \\
\text { to the government's decision to withdraw } \\
\text { from the Gaesung Industrial Complex }\end{array}$ \\
\hline $\begin{array}{l}\text { Moon Jae-in } \\
\text { (2017 Present) }\end{array}$ & $\begin{array}{l}\text { New northern } \\
\text { policy }\end{array}$ & $\begin{array}{l}\text { Launch of the Northern Economic } \\
\text { Cooperation Committee under the President. } \\
\text { Promotion of Free Trade Agreements } \\
\text { (FTAs) of South Korea and Russia/Eurasian } \\
\text { Economic Union (EAEU). } \\
\text { President's state visit to Russia (the 2nd time } \\
\text { in history since the 1s state visit of President } \\
\text { Kim Dae-jung). } \\
\text { The 3rd inter-Korean summit }\end{array}$ \\
\hline
\end{tabular}

Source: composed by the author.

However, South Korea's northern policy has yet to produce tangible results, as the progress of the policy has been overly dependent on inter-Korean relations, whose stance of each government regime toward North Korea was simply divided into either a hard-line policy or a sunshine policy. In other words, the previous South Korean governments regarded the northern policies as an extension of the North Korea policy. On the other hand, what distinguishes the new North Korean policy of Moon Jae-in's government from the previous ones is that it began to reflect the will to promote economic and political cooperation with the northern countries, separately from North Korea. Nowadays, the exchanges with the northern countries are active than it has ever been in South Korea. Under the regime of President Moon Jae-in, the conclusion of FTA with Russia and the EAEU is under negotiation. And, the president visited Russia, which is the second state visit since President Dae-jung Kim. Besides, the presidential committee on northern economic cooperation was established to build a responsible Northeast Asia Plus Community: a platform for peace and cooperation, and the New Economic Map of the Korean Peninsula.

Of course, it is difficult to see the new northern policy as completely separated from the North Korea policy, considering that it aims for a multilateral 
security and economic community amongst south-north and northern countries. However, unlike the previous northern policies, highly influenced by the North Korea policy, this new policy is rather free from an ideological propensity, as the main purpose of the policy is based on economic interests to restructure South Korean economy that are too biased on China and the USA.

\section{The South Korean FDI in the Russian Far East}

The first South Korean investment in Russia has been made since 1990. In 2019, the South Korean FDI in Russia was $\$ 99$ million, accounted for $0.2 \%$ of the total outward Korean FDI in the world. However, a boom of Korean FDI in Vietnam is a point worth noting given than Vietnam plays a main role of the "new southern policy" as same as Russia does for the "new northern policy". At this point, it seems that the new northern policy does not go smoothly compared to the new southern policy in that the Korean FDI inflows in Russia only account for $0.2 \%$ of the total outward Korean FDI. This result seems even worse compared with the BRIC countries excluding China: the Korean outward FDI in Russia is $22 \%$ of that in India, and $45 \%$ of that in Brazil, which indicates that Russia is undervalued by Korean investors compared with other competitors holding similar market attractiveness and worse geographical proximity. We can also see that the impact of the Korean FDI on the Russian economy as a whole is insignificant (Table 2).

T a b 1 e 2

The comparison of the Korean outward FDI in Russia with Vietnam \& BRIC in 2019

\begin{tabular}{c|c|c}
\hline Country & Investment $(\operatorname{mln} \$)$ & Share (\%) \\
\hline Russia & 99 & $0.2 \%$ \\
\hline Vietnam & 4,473 & $7.2 \%$ \\
\hline Brazil & 222 & $0.4 \%$ \\
\hline India & 447 & $0.7 \%$ \\
\hline China & 5,794 & $9.4 \%$ \\
\hline
\end{tabular}

Source: [1].

On the other hand, despite the weak tie at the national level, the relationship between South Korea and the Russian Far East is based on strong mutual dependence. In fact, South Korea is one of the main economic partners of the Far Eastern Federal District. As presented in Table 3, nominally, South Korea is the 4th largest investor in the Far Eastern Federal District following Bermuda, Bahamas, and Cyprus for the period 2015-2019. But, considering that investment from those three tax haven countries is presumably fictitious, it can posit that South Korea is the real largest and consistent investor in the Far Eastern Federal District. Meanwhile, Chinese and Japanese FDIs in the Far Eastern Federal District show a remarkable increase: Chinese FDI increased nearly by 7 times, while Japanese FDI has doubled for the past five years. 
The foreign direct investment in the Russian Far East by partner countries:

T a ble 3 FDI stock, million \$

\begin{tabular}{c|c|c|c|c|c}
\hline Country & $\mathbf{2 0 1 5}$ & $\mathbf{2 0 1 6}$ & $\mathbf{2 0 1 7}$ & $\mathbf{2 0 1 8}$ & $\mathbf{2 0 1 9}$ \\
\hline $\begin{array}{c}\text { Far Eastern } \\
\text { Federal District }\end{array}$ & $\mathbf{4 1 , 5 5 0}$ & $\mathbf{3 9 , 4 3 1}$ & $\mathbf{6 2 , 3 4 5}$ & $\mathbf{6 4 , 4 2 1}$ & $\mathbf{7 7 , 3 5 4}$ \\
\hline Bermuda & 14,443 & 13,177 & 21,232 & 30,744 & 29,232 \\
\hline Bahamas & 20,828 & 21,227 & 33,298 & 25,571 & 38,859 \\
\hline Cyprus & 2121 & 1,942 & 2622 & 2,969 & 3,309 \\
\hline South Korea & 158 & 164 & 231 & 135 & 205 \\
\hline Netherlands & 0 & 0 & 486 & 631 & 624 \\
\hline United Kingdom & 277 & 174 & 251 & 0 & 12 \\
\hline Japan & 52 & 57 & 95 & 116 & 119 \\
\hline China & 72 & 61 & 103 & 117 & 491 \\
\hline Hong Kong & 20 & 17 & 147 & 158 & 128 \\
\hline USA & 24 & 13 & 43 & 49 & 49 \\
\hline Others & 496 & 204 & 244 & 167 & 106 \\
\hline Undefined & 3,059 & 2,395 & 3593 & 3,764 & 4,220 \\
\hline Sourc: $[2]$ & & & & &
\end{tabular}

Source: [2].

As looking at the sub-regional distribution of the Korean FDI in the Russian Far East, its pattern completely contradicts the typical tendency of the world FDI to concentrate on Sakhalin Oblast, where the Sakhalin project to develop oil and natural gas in nine areas (mines) surrounding Sakhalin Island is underway by attracting major oil companies in the world. For this reason, in 2019, Sakhalin Oblast received $89.6 \%$ of the total FDI in the Russian Far East. However, in 2019, the largest Korean FDI is accumulated in Primorsky Krai (69.7\%) and Khabarovsk Krai (17.9\%), which have relatively attractive demand conditions based on market size and population density compared to other regions in the Far Eastern Federal District. Whereas, Sakhalin Oblast (11.1\%) is less significant to Korean investors, contradicting the typical tendency of the total foreign investments. From that, it can be postulated that the Korean FDI in the Far Eastern Federal District is primarily purposed with market seeking prior to resource seeking (Table 4).

Table 5 describes major Korean companies in the Russian Far East in terms of business sector and city. As for the business sector, it shows that the Korean FDI is concentrated on (financial, transportation, logistics and accommodation) service, trading, (electronic devices, and food and beverage) sales, and agriculture. It is also notable that Primorsky Krai and Vladivostok are the most preferred by Korean investors over Sakhalin Oblast, in terms of region and city, respectively, which indicates that Korean investors are preferably interested in marketability over resource endowments in terms of regional selections in the Far East.

On the other hand, there is no clear recent evidence officially describing the Korean investment in Sakhalin Oblast, which is the third region of the inward Korean FDI in the Russian Far East. But, based on the information shared by the 
South Korean consulate in Vladivostok in 2015, it can be confirmed that there has been investment related to energy (LNG and Gas) exploration and coal mining development by Korean companies, for instance Daewoo E\&C, Poonglim, and Korea Investment \& Securities [3].

T a ble 4

South Korea's direct investment in the Russian Far East by federal subjects: FDI stock, million \$

\begin{tabular}{c|c|c|c|c|c}
\hline & $\mathbf{2 0 1 5}$ & $\mathbf{2 0 1 6}$ & $\mathbf{2 0 1 7}$ & $\mathbf{2 0 1 8}$ & $\mathbf{2 0 1 9}$ \\
\hline $\begin{array}{c}\text { Far Eastern } \\
\text { Federal District }\end{array}$ & $\mathbf{1 5 8 . 1 4}$ & $\mathbf{1 6 4 . 6 3}$ & $\mathbf{2 4 0 . 6 2}$ & $\mathbf{1 3 5 . 2 8}$ & $\mathbf{2 0 6 . 6 1}$ \\
$\mathbf{( 1 0 0 \% )}$ & $\mathbf{( 1 0 0 \% )}$ & $\mathbf{( 1 0 0 \% )}$ & $\mathbf{( 1 0 0 \% )}$ & $\mathbf{( 1 0 0 \% )}$ \\
\hline Kamchatka & - & - & 0.06 & 0.06 & 0.05 \\
Krai & & & $(0 \%)$ & $(0 \%)$ & $(0 \%)$ \\
\hline Primorsky Krai & 96.07 & 92.17 & 178.13 & 71.79 & 144.01 \\
& $(60.7 \%)$ & $(56 \%)$ & $(74 \%)$ & $(53.1 \%)$ & $(69.7 \%)$ \\
\hline The Republic of & - & - & - & - & 2.51 \\
Buryatia & - & - & 0.01 & 0.01 & $(1.2 \%)$ \\
\hline The Republic of & - & & $(0 \%)$ & $(0 \%)$ & - \\
Sakha (Yakutia) & 25.59 & 25.41 & 27.57 & 23.95 & 22.99 \\
\hline Sakhalin Oblast & $(16.2 \%)$ & $(15.4 \%)$ & $(11.5 \%)$ & $(17.7 \%)$ & $(11.1 \%)$ \\
\hline Khabarovsk & 36.48 & 47.05 & 34.85 & 39.47 & 37.05 \\
Krai & $(23.1 \%)$ & $(28.6 \%)$ & $(14.5 \%)$ & $(29.2 \%)$ & $(17.9 \%)$ \\
\hline
\end{tabular}

Note: The share of the inward Korean FDI of the corresponding region in the total inward Korean FDI in the Far Eastern Federal District is indicated in brackets.

Source: [2].

The major South Korean companies in the Russian Far East

\begin{tabular}{|c|c|c|c|}
\hline Sector & Company & City & Business \\
\hline Manufacturing & Hyundai Welding & Artem & Welding production \\
\hline IT & City transportation system & \multirow{4}{*}{ Vladivostok } & Electronic payment system \\
\hline \multirow{2}{*}{ Trading } & Posco Daewoo & & \multirow{2}{*}{ Trading } \\
\hline & LS networks & & \\
\hline \multirow{6}{*}{$\begin{array}{l}\text { Air and Marine } \\
\text { transportation }\end{array}$} & Korean air & & Incheon-Vladivostok \\
\hline & Asiana air & Khabarovsk & $\begin{array}{l}\text { Incheon-Khabarovsk; } \\
\text { Incheon-Sakhalin }\end{array}$ \\
\hline & Jeju air & \multirow{4}{*}{ Vladivostok } & Incheon-Vladivostok \\
\hline & Tway air & & Daegu-Vladivostok \\
\hline & Air Busan & & Busan-Vladivostok \\
\hline & DBS Ferry & & The east sea-Vladivostok \\
\hline \multirow{3}{*}{ Marine logistics } & Hyundai merchant marine & \multirow{7}{*}{ Vladivostok } & \multirow{3}{*}{ Marine logistics } \\
\hline & Sinokor merchant marine & & \\
\hline & Pantos & & \\
\hline Hotel & Lotte Hotel & & $\begin{array}{c}\text { The only } 5 \text { star hotel in } \\
\text { Primorsky Krai }\end{array}$ \\
\hline \multirow{3}{*}{ Sales } & Samsung electronics & & \multirow{2}{*}{ Electronics devices } \\
\hline & LG electronics & & \\
\hline & Paldo & & Food and beverage \\
\hline
\end{tabular}




\begin{tabular}{|c|c|c|c|}
\hline Sector & Company & City & Business \\
\hline & Lotte Chilsung & & \\
\hline & Upkait & & \\
\hline \multirow{3}{*}{ Trading } & Dowsteel & & $\begin{array}{l}\text { Procurement of iron scraps } \\
\text { to export to Korea }\end{array}$ \\
\hline & Three $\mathrm{C}$ corporation & & \multirow{2}{*}{ Trading } \\
\hline & Mir special vehicles & & \\
\hline Construction & Kyeryong construction & Khabarovsk & Apartment construction \\
\hline \multirow{2}{*}{ Finance } & Woori Bank & \multirow{3}{*}{ Vladivostok } & \multirow{2}{*}{ Financial service } \\
\hline & IBK & & \\
\hline Fishing & Sajo & & Pollack fishing \\
\hline \multirow{7}{*}{ Agriculture } & Lotte international & Khorol & \multirow{7}{*}{$\mathrm{N} / \mathrm{A}$} \\
\hline & Agross & $\begin{array}{c}\text { Khorol, } \\
\text { Hanka }\end{array}$ & \\
\hline & Arro-Primorye & Ussuriysk & \\
\hline & Eco hose & Grigorievki & \\
\hline & Unigen & Khasan & \\
\hline & $\begin{array}{l}\text { Pohang federation of } \\
\text { livestock cooperatives }\end{array}$ & \multirow[t]{2}{*}{ Ussuriysk } & \\
\hline & Baridream & & \\
\hline
\end{tabular}

Source: [4].

Besides, to develop industrial clusters, the Russian government designated 20 areas in the Russian Far East as advanced special economic zones (ASEZ) as of 29 June 2020. Companies in ASEZs can benefit from tax reductions and administrative preferences. In addition, there are 22 free ports (FP) in the Russian Far East to serve as a logistic hub [5].

As of January 2020, 34 foreign companies from 11 different countries are incorporated in ASEZs. $\$ 4.2$ billion foreign capitals, equivalent to $9 \%$ of the total of domestic and foreign investment in the ASEZs, are on plan to invest. 6,670 new jobs, equivalent to $9 \%$ of the total new jobs, are projected in foreign companies. In terms of the number of corporations, three East Asian countries, namely China, South Korea, and Japan, play a great role in ASEZs based on strong economic power and geographical proximity (Table 6).

The foreign companies in ASEZs, as of January 2020

T a ble 6

\begin{tabular}{l|c|c|c|c|c|c}
\hline & China & $\begin{array}{c}\text { South } \\
\text { Korea }\end{array}$ & Japan & Australia & $\begin{array}{c}\text { New } \\
\text { Zealand }\end{array}$ & $\begin{array}{c}\text { The } \\
\text { others }\end{array}$ \\
\hline Corporations & 11 & 5 & 6 & 3 & 2 & 7 \\
\hline Investment (on plan) & \multicolumn{5}{|c}{$\$ 4.2$ billion $(9 \%)$} \\
\hline Job Creation & \multicolumn{7}{|c}{$670(9 \%)$} \\
\hline
\end{tabular}

Note: The share of foreign investment in the total of domestic and foreign investment is indicated at brackets.

Source: [6].

The 5 Korean companies in ASEZs are shown in Table 7. As for the business sector, there are: 2 companies in fisher processing; 2 companies in timber 
(processing and wood pellet); 1 company in hotel construction. It is also notable that 4 companies are related to manufacturing (processing) industry. In terms of a city, three companies are located in cities (Nadezhinskaya and Bolshoy Kamen) in Primorsky Krai. Another company is in Komsomolsk in Khabarovsk Krai. And, the other one company is at Kamchatka in Kamchatka Krai.

The Korean companies in ASEZs by a sector and a city, as of January 2020

\begin{tabular}{c|c|c}
\hline Corporation & Sector & City \\
\hline Gorod 415 LLC & Fishery processing & Kamchatka \\
\hline Hotel Pride LLC & Hotel construction & Bolshoy Kamen \\
\hline O-Yang & Fishery processing & Nadezhinskaya \\
\hline Solnechniykrug & Wood pellet & Komsomolsk \\
\hline KRW & Timber processing & Nadezhinskaya \\
\hline
\end{tabular}

Source: [6].

As of January 2020, 65 foreign companies from 13 different countries are incorporated in FPs. \$ 1.62 billion foreign capitals, equivalent to $12 \%$ of the total of domestic and foreign investment in FPs, are expected to invest. 13,432 jobs, equal to $16 \%$ of the total new jobs, will be created in foreign companies. Likewise, in FPs, China, South Korea, and Japan are the three key investing countries. But, Chinese companies are predominant in FPs in terms of the number of corporations. South Korea and Japan are following with 6 and 4 companies, which is highly behind (Table 8).

The foreign companies in FPs, as of January 2020

Table 8

\begin{tabular}{l|c|c|c|c|c|c}
\hline & China & $\begin{array}{c}\text { South } \\
\text { Korea }\end{array}$ & Japan & India & Singapore & $\begin{array}{c}\text { The } \\
\text { others }\end{array}$ \\
\hline Corporations & 42 & 6 & 4 & 3 & 2 & 8 \\
\hline Investment (on plan) & \multicolumn{5}{|c}{$\$ 1.62$ billion (12\%) } \\
\hline Job Creation & \multicolumn{7}{c}{$13,432(16 \%)$} \\
\hline
\end{tabular}

Note: The share of foreign investment in the total of domestic and foreign investment is indicated in brackets.

Source: [6].

T a ble 9

The Korean companies in FPs by a sector and a city, as of January 2020

\begin{tabular}{|c|c|c|}
\hline Corporation & Sector & City \\
\hline Vostok Polikor LLC & Life chemicals & Artem \\
\hline Urban Transport System LLC & Transportation card & Vladivostok \\
\hline Roskor LLC & Building materials & Artem \\
\hline Cristal-Golf Club LLC & Golf course & Artem \\
\hline Breese PUMP LLC & Marine pump production & Vladivostok \\
\hline Hyundai WeldingRus & Welding rod production & Artem \\
\hline
\end{tabular}

Source: [6]. 
The 6 Korean companies in FPs are shown in Table 9. The business sector shows diversities from (chemical, building material, pump, and welding rod) manufacturing to (transportation, golf) service. Whereas, it confirms that those companies are located in either Artem or Vladivostok (Table 9).

\section{Conclusions}

South Korea has pursued the northern policy since 1990 when formal diplomatic relations were signed with Russia. However, the northern policy has not yet borne visible fruits as it has been recognized not as an individual policy, but as a part of South Korea's policy on North Korea. Accordingly, President Moon Jae-in announced the new northern policy at the 3rd Eastern Economic Forum (EEF) in September 2017, and announced it as one of the top 100 national affairs. Out of the 14 target countries of the new northern policy, the Russian Far East, the closest northern zone to Korea, is recognized as the outpost of the policy due to its rich natural resources and geopolitical importance. In addition, Russia's new eastern policy, initiated in earnest from the 3rd presidency of Putin, is providing conducive foreign investment conditions by granting tax benefits and administrative convenience to companies in the Far East. Based on the analysis of South Korea's direct investment trends in the Russian Far East since 2015, this study derived the following meaningful findings.

First, South Korea's investment in Russia is rather insignificant compared to that of other BRIC countries and Vietnam, the core target country of South Korea's new southern policy. In contrast, South Korea is one of the largest investors in the Russian Far East excluding the tax haven countries. Actually, besides direct investment, South Korea is the second largest trading partner in the Far East after China. In other words, in terms of Russia as a whole, South Korea has little impact on the Russian economy compared to Europe, but in terms of the economy of the Russian Far East, South Korea is the most important economic partner.

On the other hand, as looking at South Korea's direct investment in the Russian Far East for the period 2015-2019, the increase of the FDI stock is insignificant compared to that of China and Japan. The number of South Korean companies in ASEZs and FPs is also far behind that of China, which makes it seem that the new northern policy is not producing remarkable results. In addition, South Korea and Russia have designated nine key sectors for the economic cooperation, namely, railway, electricity, gas, shipbuilding, ports, arctic routes, agriculture, forestry, fisheries and industrial complexes (known as nine bridges). However, as looking at South Korean companies in the Russian Far East, it seems that there are limited businesses related to the nine bridges, except for a few companies in agriculture, forestry, and fisheries. It can be explained that private enterprises are not easily accessible to the nine bridges projects, because the size of the project must be supported by favorable interKorean political relationships and enormous financial supports from both the 
governmental and private sectors. If the sluggish growth in the FDI stocks of the past five years continues, South Korea is likely to lose its leadership in the Russia Far East Russia to China and Japan. Therefore, the South Korean government should set up the 9-bridge projects as a long-term strategy. In the meantime, in a short-term, the government policy that encourages SMEs and startups to advance into the Russian Far East should be implemented.

In addition, contrary to other foreign investors concentrated on Sakhalin Oblast where large-scale gas and oil projects are being conducted, South Korea's investment in the Russian Far East is concentrated on Primorsky Krai, which has the best marketability among the regions in the Far Eastern Federal District. It might be difficult for South Korea, where there is no global scale energy company operating both upstream and downstream businesses simultaneously, to take a part in grand scale energy projects in that a high level of preliminary investigation is required due to a high financial risk. In reality, the South Korean companies that have entered the Russian Far East are largely small- and medium-sized and purposed with marketseeking. However, in the case of large-scale energy projects led by the Russian government, such as the Sakhalin Projects, compared to small-scale businesses in the Russian Far East at the moment, it is possible to strengthen economic cooperation at the national level. In addition, Sakhalin is a land of opportunity to dramatically improve South Korea's energy supply structure based on geographical proximity and abundant energy resource reserves. Therefore, the strong political will of the Korean government must be supported to seize this opportunity. Also, in order not to repeat the failure of the Korea National Oil Corporation, it is required to form an expert group with world-class knowledge of the oilfield development project in a long term.

\section{References}

1. Statistics of Foreign Direct Investment. (2020) Export-Import Bank of Korea. [Online] Available from: https://stats.koreaexim.go.kr/sub/countryStatistics.do. (Accessed: 16.06.2020).

2. The Central Bank of Russia. (2020) Direct Investments in the Russian Federation: Balances by Constituent Entities of the Russian Federation by Instruments and Partner Countries. [Online] Available from: https://www.cbr.ru/vfs/statistics/credit_statistics/ direct_investment/13-dir_inv.xlsx. (Accessed: 02.06.2020). IRR

3. South Korean Consulate in Vladivostok. [Online] Available from: http://overseas.mofa.go.kr/ru-vladivostok-ko/brd/m_7807/view.do?seq=1199451\&srchFr $=$ \&amp; $\operatorname{srchTo}=\& a m p ; s r c h W o r d=\% \mathrm{EC} \% 82 \% \mathrm{AC} \% \overline{\mathrm{ED}} \% 95 \% \mathrm{~A} 0 \% \mathrm{~EB} \% \mathrm{~A} 6 \% \mathrm{~B} 0 \& \mathrm{amp} ; \mathrm{srchTp}$ $=0 \& a m p ; m u l t i \_i t m \_s e q=0 \& a m p ; i t m \_s e q \_1=0 \& a m p ; i t m \_s e q \_2=0 \& a m p ; c o m p a n y \_c d=\& a m p$ ;company_nm $=\&$ page $=1$. (Accessed: 14.04.2020).

4. Korea Trade-Investment Promotion Agency. [Online] Available from: http://news.kotra.or.kr/user/globalBbs/kotranews/6/globalBbsDataView.do?setIdx=322\&dataI $\mathrm{dx}=169308$. (Accessed: 14.04.2020).

5. The Roscongress Foundation. [Online] Available from: https://forumvostok.ru/. (Accessed: 16.06.2020).

6. South Korean Consulate in Vladivostok. [Online] Available from: http://overseas.mofa.go.kr/ru-vladivostok-ko/brd/m_7808/view.do?seq=1329750\&srchFr= \&amp;srchTo=\&amp;srch Word=\&amp;srchTp=\&amp;multi_itm_seq=0\&amp;itm_seq_1= $0 \& a m p ; i t m \_s e q \_2=0 \& a m p ;$ company_cd $=\& a m p ;$ company_nm $=\&$ page $=1$.

16.06.2020). 
The Sub-National Distribution of South Korean Foreign Direct Investment in Russia: A Focus on the Russian Far East

Vestnik Tomskogo gosudarstvennogo universiteta. Ekonomika - Tomsk State University Journal of Economics. 2020. 52. pp. 280-290. DOI: 10.17223/19988648/52/17

Han-Sol Lee, Peoples' Friendship University of Russia (Moscow, Russian Federation). E-mail: 1i-kh@rudn.ru

Keywords: foreign direct investment, Russian Far East, South Korean economy, Russian economy, Eurasian economy.

Субнациональное распределение прямых иностранных инвестиций (ПИИ) Южной Кореи в России: ориентировано на российский Дальний Восток

\section{Х.-С. Ли}

В данной статье исследуются корейские прямые иностранные инвестиции (ПИИ) на российском Дальнем Востоке - значимой области для разработки новой северной политики Южной Кореи и поворота России на Восток. В отличие от незначительного влияния корейских ПИИ на российскую экономику в иелом, Южная Корея - один из ключевых экономических партнеров на российском Дальнем Востоке. На период 20152019 г2. Южная Корея является 4-м крупнейшим инвестором на Дальнем Востоке России. В 2019 г. 69,7\% корейских инвестищий на Дальнем Востоке России сосредоточено в Приморском крае, что противоречит общей тенденции, согласно которой мировые инвестиции на Дальнем Востоке России сильно перекошены в Сахалинскую область для участия в газовых и нефтяных проектах. Это свидетельствует о том, что корейские ПИИ на Дальнем Востоке России направлены на поиск рынка, а не ресурсов. Кроме того, из-за высокого барьера входа 9 мостов существует ограниченное количество компаний в 9 мостах-отраслях промылиленности.

Ключевые слова: прямые иностранные инвестиции, российский Дальний Восток, южно-корейская экономика, российская экономика, евразийская экономика. 